\title{
Kognitivno-vedenjska terapija pri otrocih in mladostnikih s kronično bolečino
}

\author{
KO za otroško, mladostniško in razvojno nevrologijo, Pediatrična klinika, Univerzitetni klinični center Ljubljana
}

\begin{abstract}
Povzetek: Kronična ali ponavljajoča se bolečina $\mathrm{v}$ otroštvu je dokaj pogost pojav, s katerim se psihologi srečujemo $\mathrm{v}$ okviru multidisciplinarne zdravstvene obravnave. $\mathrm{V}$ tem članku skušava avtorici osvetliti teoretična izhodišča in praktične usmeritve pri obravnavi kronične bolečine pri otroku in mladostniku. Za ustrezno razumevanje kronične bolečine je treba upoštevati biološke/ fiziološke, kognitivne, čustvene in socialne dejavnike. V prvem delu članka skušava povzeti izsledke novejših študij glede povezanosti navedenih dejavnikov z razvojem kronične bolečine. V ospredje postavljava teorijo razumevanja in obravnave kronične bolečine pri otroku in mladostniku, ki izhaja iz kognitivno-vedenjske teorije. V drugem delu članka so uporabno in sistematično predstavljene metode kognitivno-vedenjske terapije, od ocenjevanja bolečine, spremljanja oz. monitoringa v terapiji do psihoedukacije, kognitivnih in vedenjskih tehnik.
\end{abstract}

Ključne besede: kronična bolečina, otroci in mladostniki, kognitivno-vedenjska terapija

\section{Cognitive-behavioural therapy in children and adolescents with chronic pain}

\author{
Department of Paediatric Neurology, Division of Paediatrics, University Medical Centre Ljubljana, Slovenia
}

\begin{abstract}
Chronic or recurrent pain in childhood is a common phenomenon, which psychologists encounter in their work within a multidisciplinary care team. In this article, we try to shed some light on the theoretical background and practical guidelines when dealing with chronic pain in children and adolescents. To understand chronic pain properly, biological/physiological, cognitive, emotional, behavioural and social factors need to be taken into consideration. In the first part of the article, we try to summarize the results of recent studies on the connection between these factors and the development of chronic pain. We highlight the theory of understanding and treating chronic pain in children and adolescents based on cognitive-behavioural theory. The second part of the article deals with the methods of cognitive-behavioural therapy for assessing and monitoring pain, psychoeducation, and specific cognitive and behavioural techniques in a systematic and practical fashion.
\end{abstract}

Keywords: chronic pain, children and adolescents, cognitive-behavioural therapy

\footnotetext{
*Naslov/Address: dr. Staša Stropnik, KO za otroško, mladostniško in razvojno nevrologijo, Pediatrična klinika, Univerzitetni klinični center Ljubljana, Bohoričeva 28, 1000 Ljubljana, e-mail: stasa.stropnik@kclj.si

Članek je licenciran pod pogoji Creative Commons Attribution 4.0 International licence. (CC-BY licenca). The article is licensed under a Creative Commons Attribution 4.0 International License (CC-BY license).
} 


\section{Opredelitev in razširjenost kronične bolečine med otroki in mladostniki}

Bolečino definiramo kot kronično, če traja neprestano vsaj tri mesece. O ponavljajoči se bolečini (angl. recurrent pain) pa govorimo, če se ponavlja v epizodah znotraj najmanj trimesečnega obdobja in je posameznikovo delovanje zaradi nje ovirano (Dahlquist in Switkin, 2009). V otroštvu kronična bolečina ni redek pojav. Najpogostejše kronične bolečine $\mathrm{v}$ otroštvu so mišično-skeletna bolečina, glavoboli in bolečine v trebuhu. Glede na pregledno epidemiološko študijo (King, Chambers, Huguet, MacNevin, McGrath in MacDonald, 2011), ki je vključevala 41 epidemioloških raziskav po letu 1991, se kronični glavobol v populaciji pojavlja pri $23 \%$ otrok in mladostnikov. Ostali tipi kronične bolečine (bolečina $\mathrm{v}$ trebuhu, mišično-skeletna bolečina in kombinirana bolečina) so bili proučevani redkeje, a so prav tako precej pogosti, saj se pojavljajo pri 11 do 38 \% populacije otrok. Študije kažejo, da je kronična bolečina pogostejša pri deklicah in da se njen delež povišuje s starostjo otrok.

Kronična ali ponavljajoča se bolečina je lahko primarna (npr. migrena ali bolečina $\mathrm{v}$ trebuhu v okviru funkcionalnih gastroenteroloških motenj) ali sekundarna, saj spremlja primarno kronično bolezen (npr. revmatoidni artritis) (Palermo idr., 2012). V novejši literaturi se uporablja v zvezi s kronično in ponavljajočo se bolečino termin primarna bolečinska motnja, ki ga je prvi predlagal Schechter leta 2014 in naj bi nadomestil manj ustrezen termin funkcionalni bolečinski sindrom. Nov termin poudarja, da je primarna bolečina sama zase motnja, ki izhaja iz danes poznanega sovplivanja fizioloških in psiholoških procesov (Schechter, 2014). Današnje razumevanje primarne bolečinske motnje in pristope $\mathrm{k}$ obravnavi povzema pregledni članek avtorjev Friedrichsdorfa, Giordana, Desai Dakoji, Warmutha, Daughtry in Schulza iz leta 2016, ki je kratko povzet v nadaljevanju. Raziskave, predvsem tiste na enojajčnih dvojčkih, kažejo, da gre v osnovi različnih kliničnih slik kronične bolečine za skupno biološko podlago - občutljivost za bolečino. Patofiziologija pri trebušnih bolečinah, primarnih glavobolih, mladostniški fibromialgiji in drugih podobnih stanjih ima skupno osnovo. Primarna bolečinska motnja je povezana s pomembno oviranostjo v vsakodnevnem življenju in ni povezna $\mathrm{z}$ boleznijo $\mathrm{v}$ konvencionalnem smislu (le-ta predpostavlja biokemično ali strukturno motnjo v organizmu). Prav tako primarne bolečinske motnje ni možno zdraviti enoznačno s klasičnim medicinskim pristopom, ampak pogosto zahteva večstopenjski in timski pristop.

$\mathrm{S}$ kronično bolečino povezujemo tudi motnje, ki sicer sodijo v okvir duševnih motenj. V Diagnostičnem in statističnem priročniku duševnih motenj DSM-5 (American Psychiatric Association, 2013) je kronična bolečina vključena v poglavje Motnje s telesnimi simptomi in sorodne motnje. $\mathrm{V}$ to poglavje sodita diagnostična kategorija hlinjene motnje, ki imajo bolj ali manj zavestno motivacijo, in diagnostična kategorija motnje s telesnimi simptomi in s prevladujočo bolečino, katerih motivacija je nezavedna. Koncept razumevanja motenj s telesnimi simptomi (npr. bolečino) postavlja v ospredje pacientove pretirane oz. disfunkcionalne misli, čustva in vedenja v zvezi s telesnimi simptomi. Ni več pomembno, ali so simptomi medicinsko pojasnjeni ali ne, ampak je za postavitev diagnoze pomembno disfunkcionalno doživljanje le-teh. Motnja poudarjene telesne simptomatike se lahko pojavlja pri resnično bolnih ali pri zdravih in tako presega dvojnost razumevanja telesa in duševnosti (American Psychiatric Association, 2013).

\section{Razumevanje in obravnava kronične bolečine v luči kognitivno-vedenjskega modela}

Za razlago kompleksnosti doživljanja bolečine je zelo uporaben kognitivno-vedenjski teoretični model. S stališča kognitivno-vedenjske teorije ima bolečina fiziološki, zaznavni, kognitivni, čustveni, vedenjski in medosebni vidik (Carr, 2016). Prepletanje vseh teh vidikov pojasnjuje, zakaj je doživljanje bolečine vedno subjektivno. V nadaljevanju poglavja avtorici kratko povzemava spoznanja raziskovalcev o posameznih vidikih bolečine, ki vsak zase predstavljajo možno vstopno točko za uporabo določenih kognitivnovedenjskih ukrepov v terapiji kronične bolečine.

$\mathrm{Na}$ fiziološki ravni gre za proces resničnega ali pričakovanega (anticipiranega) draženja nociceptorjev in prenos sporočil možganom. Pionirja modernega razumevanja kronične bolečine Melzack in Wall, avtorja teorije vrat, sta pokazala, da je lahko ta proces centralno moduliran, tako da ni jasne povezave med obsežnostjo poškodbe in zaznano jakostjo bolečine. V svojem članku Pain mechanisms, kjer natančno pojasnjujeta fiziološke mehanizme bolečine, govorita tudi o pomenu psiholoških dejavnikov (preteklih izkušenj, pozornosti in čustev), ki vplivajo na bolečinski odgovor in zaznavo bolečine $\mathrm{z}$ delovanjem na sistem nadzora vrat bolečine (Melzack in Wall, 1965). Novejši avtorji še natančneje proučujejo razvoj in vzdrževanje kronične bolečine $z$ dolgotrajnimi spremembami različnih medsebojno povezanih perifernih, hrbtenjačnih in možganskih okrožij, ki se prepletajo v posameznikovem izkustvu bolečine (Liossi in Howard, 2016). Vključujejo se predvsem limbični sistem in amigdala, sprednja cingulatna in ortbitofrontalna skorja, insula ter hipokampus, ki modulirajo bolečino s kognitivnimi in čustvenimi procesi, kot so pozornost, pričakovanja, zaznana zmožnost nadzora in tesnoba. Prepletanje psiholoških in bioloških procesov razloži, kako lahko procesi nevroplastičnosti in senzitizacije prispevajo $h$ kronifikaciji glavobola oziroma bolečine in komorbidnih težav na področju razpoloženja in kognicije (Nicholson, Houle, Rhudy in Norton, 2007).

$\mathrm{Na}$ zaznavni ravni se občutenje bolečine razlikuje po jakosti, kakovosti in trajanju. Na kognitivni ravni sta jakost in trajanje bolečine povezana s stopnjo pozornosti na poškodbo ali bolečino, $\mathrm{z}$ doživljanjem bolečine kot ogrožajoče in $\mathrm{z}$ doživljanjem lastne nezmožnosti nadzora nad bolečino (Carr, 2016). Številne študije v zadnjih 30 letih so potrdile povezavo med $\mathrm{z}$ bolečino povezanimi prepričanji in intenziteto bolečine, telesno manjzmožnostjo in psihosocialnimi težavami (depresija, znižana aktivnost in manjše socialno vključevanje) (Gatchel, Peng, Peters, Fuchs in Turk, 2007; v Ehde, Dillworth and Turner, 2014). Več novejših študij in avtorjev postavlja $\mathrm{v}$ ospredje kognitivni slog procesiranja bolečine (kot npr. katastrofiziranje), ki vpliva na zaznano bolečino in spremljajočo čustveno izkušnjo, povzemajo $\mathrm{v}$ 
članku Friedrichsdorf in soavtorji (2016). Katastrofiziranje predstavlja negativne čustvene in kognitivne procese poudarjanja pomena bolečine, premlevanja oz. ruminacije (anksiozno preokupacijo z bolečino), pesimizem in občutek nemoči ob bolečih občutkih. Več raziskav kaže povezanost otrokovih vedenj $\mathrm{v}$ zvezi $\mathrm{z}$ bolečino in katastrofiziranjem bolečine S strani staršev (Friedrichsdorf idr., 2016). Pričakovanja in kognicije staršev vplivajo na oblikovanje otrokovih spominov na bolečino, kar so Noel, Rabbitts, Ghafari Tai in Palermo (2015) raziskovali pri otrocih po operativnem posegu. Negativni spomini v zvezi z bolečino se stopnjujejo $\mathrm{z}$ mehanizmi katastrofiziranja, in sicer bolj $\mathrm{s}$ strani staršev kakor s strani otroka.

$\mathrm{Na}$ čustveni ravni se s kronično bolečino povezujeta tesnoba in depresivnost. Martin, McGrath, Brown in Katz (2007) so v študiji otrok in mladostnikov s kronično bolečino ugotovili, da je strah pred bolečino pomemben napovednik stopnje oviranosti. Zaradi strahu pred bolečino se prizadeti začne izogibati dejavnostim, s tem pa se stopnjuje oviranost zaradi bolečine. Obsežna nemška študija na splošni populaciji otrok in mladostnikov (Kröner - Herwig in Gassmann, 2012) je ugotavljala, kateri psihološki, vedenjski in socialni dejavniki so povezani $\mathrm{z}$ določenim tipom glavobola (migrenskim in tenzijskim). Med psihološkimi spremenljivkami so bili simptomi ponotranjanja (internalizacije) najpomembnejši napovednik vseh tipov glavobola, kar se potrjuje tudi $\mathrm{v}$ drugih študijah, najmočneje pa so se povezovali z migrenskim tipom glavobola. V regresijski analizi sta se občutljivost za anksioznost in somatosenzorno ojačevanje pokazala kot pomembna in specifična dejavnika glavobola. Avtorji menijo, da lahko ta dva dejavnika, ki vključujeta pretirane reakcije posameznika na telesne senzacije, predstavljata most med biološkim in čustvenim delovanjem posameznika.

Med začetniki proučevanja vedenjskega vidika bolečine je pomemben avtor Wilbert Fordyce, ki je povezal vedenjsko teorijo oz. načela instrumentalnega pogojevanja $\mathrm{z}$ bolečinskim vedenjem. V članku Vedenjska znanost o kronični bolečini zapiše, da je edini način, da okolica bolečino prepozna, pravzaprav pacientovo vedenje, ki nam sporoča bolečino z vidnimi in slušnimi sporočili (Fordyce, 1984). Tako kot na druga vedenja lahko vplivamo tudi na bolečinsko. Bolečinsko vedenje se lahko pojavi v odsotnosti nocicepcije $\mathrm{z}$ neposrednim pozitivnim ojačevanjem, lahko pa tudi posredno $\mathrm{z}$ izogibanjem negativnim posledicam (učenje z izogibanjem). Bolečinsko vedenje je lahko naučeno ali oblikovano s socialnimi reakcijami iz okolja. Pri otrocih so posebno pomembne reakcije staršev na otrokovo vedenje ob bolečini, zato moramo v terapevtski načrt vključiti tudi delo s starši. Na vedenjski in medosebni ravni je bolečnina povezana $\mathrm{z}$ izogibanjem situacijam, ki zahtevajo dodatne napore, $\mathrm{z}$ razdražljivostjo in osiromašenjem medvrstniških odnosov (Carr, 2016).

Skognitivno-vedenjskoterapijolahkonabolečinovplivamo z delovanjem na vsakega od naštetih vidikov bolečine. $\mathrm{Na}$ fiziološko raven lahko vplivamo s psihofiziološkimi metodami, kot so sprostitvene tehnike in metoda biološke povratne zanke (biofeedback). Na kognitivne vidike vplivamo $\mathrm{s}$ poučevanjem otrok o tehnikah preusmerjanja misli in $\mathrm{s}$ spreminjanjem stališč o neobvladljivosti bolečine. Pomembno je tudi delo na prepričanjih staršev (edukacija, zmanjševanje zaskrbljenosti in katastrofiziranja ...). $\mathrm{Z}$ vedenjskimi tehnikami lahko spreminjamo neželene vedenjske vzorce, povezane $\mathrm{z}$ bolečino, $\mathrm{v}$ konstruktivnejše, torej takšne, ki so usmerjeniv obvladovanje bolečine, zmanjševanjeizogibalnega vedenja in aktivacijo. Na medosebnem področju pomagamo otrokom z zniževanjem ravni stresa in krepitvijo socialne podpore v družini, šoli in vrstniški skupini (Carr, 2016). Ne glede na to, kateri dejavniki (biološki, psihološki ali socialni) pri nastanku kronične bolečine pri posameznem bolniku prevladujejo, je pristop k obravnavi v osnovi enak, čeprav $\mathrm{z}$ različnimi poudarki glede na ugotovljene dejavnike.

Pri otrocih in mladostnikih se glede na objavljene študije med tehnikami kognitivno-vedenjske terapije najpogosteje uporablja sproščanje, biofeedback in učenje staršev zaizvajanje tehnike instrumentalnega pogojevanja $\mathrm{z}$ bolečino povezanih vedenj, nekaj študij pa zajema tudi kognitivne tehnike (Palermo, Eccleston, Lewandowski, Williams and Morley, 2010). Vključevanje staršev v programe rehabilitacije otrok s kronično bolečino je pomemben dejavnik napredka otrok pri njihovem funkcioniranju in zmanjševanju bolečine, so v študiji pokazali avtorji Sieberg, Smith, White, Manganella, Sethna in Logan (2016). Program v študiji je prispeval k bolj ustreznim odzivom staršev na otrokovo bolečino, saj se je zmanjšalo pretirano zaščitniško vedenje pri materah.

Eccleston, Morley in Williams so sistematično pregledali objavljene članke o psiholoških terapijah za obvladovanje bolečine. Ločeno so pregledali študije odraslih in otrok, ki so zadostile določenim merilom (Eccleston, Morley in Williams, 2013). Večina študij se nanaša na odraslo populacijo in večji delež študij je prikazoval kognitivno-vedenjske terapije. Kognitivno-vedenjska terapija se je pokazala kot učinkovita za obvladovanje bolečine, izboljšanje razpoloženja in funkcioniranja, vendar učinki terapije niso bili veliki. Za razliko od študij na odrasli populaciji je bil učinek kognitivnovedenjske terapije na stopnjo bolečine in funkcioniranje pri otrocih in mladostnikih višji. Pri pregledu 37 študij psiholoških terapij bolečine otrok in mladostnikov (od tega je bilo 21 študij terapij glavobola) se je pokazalo v $50 \%$ olajšanje bolečine takoj po krajši kognitivno-vedenjski obravnavi, ki jo izvajajo usposobljeni nepsihologi. Učinek izboljšanja je vztrajal tudi pri kasnejših vrednotenjih programov. Avtorji preglednega članka sklenejo, da kognitivno-vedenjska terapija pri obravnavi pediatrične bolečine predstavlja najuspešnejši terapevtski pristop nasploh.

\section{Kognitivno-vedenjska terapija otrok in mladostnikov s kronično bolečino}

Kognitivno-vedenjska terapija se je izkazala za učinkovito pri obravnavi različnih vrst kronične bolečine (Eccleston, Palermo, Williams, Lewandowski in Morley, 2009; Morley, Eccleston in Williams, 1999; Sieberg, Huguet, von Baeyer in Seshia, 2012; Turner, Mancl in Aaron, 2006), tudi pri otrocih in mladostnikih (Eccleston, Morley, Williams, Yorke in Mastroyannopoulou, 2002; Palermo, Wilson, Peters, Lewandowaki in Somhegzi, 2009; Eccleston idr. 2013). Obravnava kronične bolečine s kognitivno-vedenjsko terapijo lahko pomembno izboljša posameznikovo kakovost življenja in zmanjša potrebo po medicinskih ukrepih (Hunfeld idr., 2001; Otis, 2007). Poudarek pri kognitivno-vedenjski terapiji kronične bolečine je predvsem na vedenjski aktivaciji in 
spreminjanju negativnih avtomatskih misli in prepričanj, ki so povezana $\mathrm{z}$ bolečino.

\section{Ocenjevanje kronične bolečine}

Zbiranje informacij o otroku in bolečini ter psihološka ocena otroka s kronično bolečino je ključnega pomena za to, da lahko načrtujemo ustrezno obravnavo in uporabimo učinkovite ukrepe (Palermo, 2012). Z oceno predizpozicijskih, sprožilnih, vzdrževalnih in varovalnih dejavnikov oblikujemo formulacijo in načrt pomoči za posameznika s kronično bolečino (Carr, 2016). Avtorica T. M. Palermo (2012) opisuje, kako pomembno vlogo pri posameznikovem vsakodnevnem funkcioniranju ima lahko kronična bolečina. Bolečina lahko vpliva na mladostnikovo učno uspešnost, prisotnost $\mathrm{v}$ šoli, na odnose $\mathrm{z}$ vrstniki in drugimi družinskimi člani. Zato skušamo pri obravnavi pacienta s kronično bolečino oceniti področja bolečine, čustvenega in fizičnega funkcioniranja, higieno spanja in druge življenjske navade, odnose $\mathrm{v}$ družini in $\mathrm{z}$ vrstniki ter učno uspešnost. Za zbiranje informacij lahko uporabimo kognitivno-vedenjski intervju, standardizirane vprašalnike in lestvice, monitoring, po potrebi pa tudi druge standardizirane psihološke preizkuse (npr. za oceno intelektualnih sposobnosti) (Palermo, 2012). Ocenjevanje pacienta $\mathrm{s}$ kronično bolečino naj bi potekalo $\mathrm{v}$ skladu z biopsihosocialnim modelom: pridobimo informacije o otrokovi bolečini (npr. začetek, pogostost, trajanje, intenzivnost), fizičnih in bioloških dejavnikih (npr. informacije o morebitnih boleznih otroka, kroničnih bolečinah pri drugih družinskih članih), socialnih in okoljskih dejavnikih, ki vplivajo na posameznikov odziv na bolečino (npr. odziv staršev in drugih družinskih članov na bolečino), kognitivne in čustvene značilnosti otroka ali mladostnika (npr. strategije spoprijemanja, depresivnost) in informacije o življenjskem slogu posameznika (Palermo, 2012). Pri zbiranju informacij je ključno sodelovanje strokovnjakov, ki obravnavajo otroka oziroma mladostnika. Od zdravnikov npr. pridobimo informacije glede somatskega ozadja kronične bolečine oziroma glavobola - ali ugotovljena somatska patologija pojasnjuje nastanek in vzdrževanje bolečine. Če organskega vzroka ni, smo pri oceni otrokovih težav bolj osredotočeni na prepoznavo funkcije bolečine. Posebej smo pozorni na morebitno funkcijo izogibanja, sporočanja stiske, pridobivanja pozornosti ali nekih drugih ugodnosti, ki jih bolečina prinaša (Carr, 2016). Med psihološkim ocenjevanjem otroka oz. mladostnika ne smemo pozabiti na morebitne pridružene psihološke motnje (npr. anksioznost, depresivnost) (Dorn idr., 2003; Kashikar-Zuck idr., 2008; Noel, Groenewald, BealsErickson, Gebert in Palermo, 2016).

\section{Metode ocenjevanja}

\section{Kognitivno-vedenjski intervju}

Intervju je najpomembnejši del ocenjevanja otroka $\mathrm{s}$ kronično bolečino ali glavobolom (Palermo, 2012). Hkrati predstavlja priložnost za starše in otroka, da spregovorijo o svojem doživljanju bolečine in o vplivu bolečine na njihovo življenje. $\mathrm{V}$ intervjuju skušamo pridobiti informacije o naslednjih področjih (Palermo, 2012):
Pridobivanje informacij 0 bolečini in $z$ bolečino povezanih vedenjih. Posameznika vprašamo o tem, kdaj se je bolečina prvič pojavila, o najhujši in običajni intenzivnosti bolečine, o njenem mestu, pogostosti in trajanju. Pri ocenjevanju jakosti bolečine si lahko pomagamo z lestvico od 1 (ni bolečine) do 10 (najhujša bolečina), pri mlajših otrocih pa tudi s pomočjo slikovnih gradiv, 'bolečinskega termometra" ipd. S pomočjo ocenjevanja jakosti bolečine otroku pojasnimo, da se bolečina pojavlja v razponu od blažje do močneje izražene in da pri določeni stopnji bolečine lahko čisto običajno funkcionirajo, pri višji stopnji pa nekaterih stvari ne morejo početi. Pri opisovanju mesta bolečine si pri mlajših otrocih lahko pomagamo s sliko telesa, na kateri otrok označi mesto bolečine. Pomemben del pridobivanja informacij o zgodovini bolečine je prepoznava vzorcev in sprožilcev ter običajne strategije soočanja $z$ bolečino. Bolečina je na primer lahko hujša zjutraj kot zvečer, ob dnevih, ko je šola, medtem ko ob prostih dnevih bolečine ni ipd. Povprašamo o vedenjih pomembnih drugih ob otrokovih glavobolih (npr. staršev, sorojencev, vrstnikov, učiteljev ipd.) in skušamo prepoznati, ali ti s svojimi odzivi nehote krepijo otrokovo doživljanje bolečine in s tem povezana vedenja (Carr, 2016).

Otroka in starše povprašamo o do sedaj uporabljenih strategijah soočanja $\mathrm{z}$ bolečino, o morebitni uporabi alternativnih metod zdravljenja in o uspešnosti dosedanjih poskusov obvladovanja bolečine. Preverimo tudi prepričanja staršev in otroka o bolečini, kaj jo po njihovem mnenju povzroča ter kaj pričakujejo od obravnave. Če se izkaže, da pričakujejo, da bo bolečina popolnoma izginila, jim pojasnimo, da je realnejši cilj navadno uspešnejše funkcioniranje in soočanje $\mathrm{z}$ bolečino in da je verjetnost, da bo bolečina čisto izginila in se ne bo nikoli več pojavila, zelo majhna. Vedno pridobimo tudi informacije o medikamentozni terapiji bolečine - ali morda redno jemlje kakšna zdravila, kolikokrat vzame protibolečinsko terapijo, ali mu ta pomaga ipd. (Palermo 2012).

Ocena vedenja in čustvovanja. Ocena vedenja in čustvovanja je pri otroku s kronično bolečino zelo pomembna, saj so čustvene težave (anksioznost, depresivnost) pri njih zelo pogoste (Noel, idr., 2016; Palermo, 2012). Čustvene težave lahko so lahko predhodnica kronični bolečini ali se pojavijo kot posledica doživljanja kronične bolečine. Pomembno je pridobiti natančne informacije o otrokovem trenutnem razpoloženju in razpoloženju pred pojavom bolečine, o anksioznosti in drugih čustvenih težavah. Pri ocenjevanju vedenja in čustvovanja pogosto uporabimo standardizirane ocenjevalne lestvice (npr. ASEBA, Achenbach in Rescorla, 2001, Vprašalnik prednosti in težav - SDQ, Goodman, 1997, Revidirana lestvica anksioznosti in depresije - RCADS, Chorpita, Moffitt in Gray, 2005, Vprašalnik depresivnosti - CDI, Kovacs, 1985 ipd.). Pozorno ocenimo tudi otrokovo vedenje, saj je zmanjšana dejavnost zelo pogosta pri posameznikih s kronično bolečino (Palermo, 2012; Carr, 2016). Zmanjšana dejavnost je lahko posledica kronične bolečine, ki lahko povzroči slabšo telesno pripravljenost (slabšo kondicijo), kar še poslabša kronično bolečino. Pri ocenjevanju vedenja otroka in starše povprašamo o vplivu bolečine na posameznikovo vsakodnevno funkcioniranje (npr. hojo, hranjenje), šolske obveznosti (npr. delanje domačih nalog, prisotnost v šoli), fizične aktivnosti (npr. ples, športni 
treningi) ter aktivnosti $\mathrm{z}$ vrstniki in družino. Povprašamo tudi o prehranjevalnih navadah, kajenju, uživanju kofeina, alkohola itd. ter o higieni spanja (navade, povezane s spanjem, količina spanja ipd.). Otroka povprašamo o odnosih v družini, odnosih z vrstniki in učitelji ter kako se zanj pomembni drugi odzivajo na njegovo bolečino.

Ocena otrokovega funkcioniranja $v$ šoli. Kronična bolečina pogosto vpliva tudi na otrokovo funkcioniranje $\mathrm{v}$ šoli (Logan, Simons, Stein in Chastain, 2008; Palermo, 2012). $\mathrm{V}$ intervjuju pridobimo informacije o otrokovi prisotnosti $\mathrm{v}$ šoli oziroma kolikokrat je zaradi bolečine manjkal v šoli, kakšen je njegov učni uspeh in ali so se ocene zaradi glavobolov poslabšale. Če gre za kronične bolečine brez jasnega organskega izvora in otrok zaradi bolečine izostaja od pouka, smo še posebej pozorni na otrokovo počutje v šoli, vrstniške odnose v šoli in otrokove intelektualne sposobnosti, ki jih po potrebi tudi ocenimo. Pomembno je izvedeti, kakšen je odziv učiteljev in sošolcev na otrokovo bolečino ter koliko pozornosti in prilagoditev $\mathrm{v}$ šoli otrok dobi zaradi bolečine.

\section{Beleženje}

Pri uporabi dnevnikov/koledarčkov bolečine, v katere pacient beleži pojavljanje bolečine, intenzivnost bolečine, kako dolgo je trajala, dogodke pred pojavom bolečine in takoj po njem, kakšno strategijo soočanja $\mathrm{z}$ bolečino je pacient uporabil ipd., moramo biti zelo previdni (Carr, 2016; Palermo, 2012). Po eni strani lahko s pomočjo beleženja ocenjujemo učinkovitost terapevtskega ukrepa, prepoznamo lahko morebitne sprožilne in vzdrževalne dejavnike bolečine ipd. Po drugi strani pa lahko dolgotrajen monitoring bolečine usmerja pozornost pacienta in drugih družinskih članov na bolečino, zato se za monitoring bolečine vedno odločamo individualno in ga ne izvajamo več kot en ali dva tedna.

S pomočjo informacij, zbranih z intervjuji in ocenjevalnimi lestvicami, oblikujemo konceptualizacijo primera, ki vključuje predispozicijske, sprožilne, vzdrževalne in varovalne dejavnike (Carr, 2016). Pomembno je, da pridobimo čim več informacij o pacientovem delovanju v različnih okoljih, zato je koristno sodelovanje s šolo, starši in drugimi družinskimi člani. S pomočjo formulacije problema nato oblikujemo načrt kognitivno-vedenjske terapije.

\section{Psihoedukacija}

Študije kažejo, da učinkovita obravnava otrok in mladostnikov s kroničnimi bolečinami oziroma glavoboli temelji na večstopenjskem, na družino osredinjenem pristopu, ki vključuje psihoedukacijo, zmanjšanje izvorov stresa v družini, šoli in medvrstniški skupini, delo s starši (trening starševskih spretnosti) in priučitev spretnosti obvladovanja bolečine (Andrasik in Schwartz, 2006; Hermann, 2011; Palermo, Eccleston, Lewandowski, Williams in Morley, 2010). Tako otroku kot staršem v okviru psihoedukacije najprej pojasnimo, da $\mathrm{k}$ nastanku in vzdrževanju kronične bolečine pomembno prispevajo tako fizični kot psihološki dejavniki (Palermo, 2012). Poudarimo, da napotitev $\mathrm{v}$ psihološko obravnavo ne pomeni, da otroku ne verjamemo, da ga boli ali da si bolečino izmišlja. Če gre za kronični glavobol, si pri psihoedukaciji lahko pomagamo z modelom kroničnega glavobola, ki je predstavljen na sliki 1, ob drugih kroničnih bolečinah pa lahko oblikujemo podoben model. $\mathrm{V}$ psihoedukacijo vključimo tudi informacije o različnih vrstah bolečine (akutna in kronična), o tem, da nas akutna bolečina lahko zaščiti pred nadaljnjimi poškodbami, da nas navadno spodbudi $\mathrm{k}$ akciji, k odpravljanju bolečine, medtem ko nas kronična bolečina navadno ohromi, otopi. Zaradi različnih mehanizmov nastanka in vzdrževanja akutne in kronične bolečine je tudi obravnava obeh različna. Velikokrat strategije, ki so učinkovite pri spopadanju z akutno bolečino, pri kronični ne pomagajo (Palermo, 2012). Staršem in otroku nato razložimo, da je bistveno opustiti (vsaj začasno) iskanje vzroka kronične bolečine in da je treba vso energijo usmeriti $\mathrm{k}$ učenju obvladovanja otrokove bolečine in zmanjševanja negativnih učinkov, ki jih ima na njihovo življenje. Pojasnimo jim, da so kakovost življenja, posameznikovo funkcioniranje, razpoloženje, socialni odnosi in pozitivne dejavnosti tisto, kar pomembneje prispeva $\mathrm{k}$ uspešnemu delovanju posameznika kot intenzivnost bolečine (Skevington, 1998). Nato preidemo na razlago kognitivno-vedenjskega modela in metod. Staršem in otroku rečemo, da želimo s pomočjo kognitivnovedenjske terapije vplivati na to, kako se otrokovi možgani, telo in živčni sistem odzovejo na bolečino. Razložimo jim že omenjeno teorijo vrat za bolečino. Pojasnimo, da se pri kognitivno-vedenjski terapiji kronične bolečine najpogosteje osredinimo na misli, prepričanja in čustva, ki so lahko povezana $\mathrm{z}$ doživljanjem kronične bolečine (Palermo, 2012). Otroku skušamo povezanost misli, čustev in vedenja predstaviti na konkretnem primeru iz njegovega življenja. Za lažje prepoznavanje misli otroka in starše naučimo beleženja avtomatskih misli, ki se pojavijo npr. ob začetku glavobola, postopoma pa beleženju dodamo še čustva, ki so se pojavila ob teh mislih. Na podlagi zabeleženih misli in čustev, povezanih s kronično bolečino, otroku razložimo, kako avtomatske misli prispevajo $\mathrm{k}$ posameznikovemu odzivu na bolečino in njegovemu vedenju ob bolečini. $\mathrm{Z}$ otrokom nato oblikujemo koristnejše oziroma manj disfunkcionalne misli o bolečini - npr. če otrok ob pojavu bolečine pomisli ' Nikoli mi ne bo bolje", lahko skupaj oblikujemo misel 'Znam se soočiti z bolečino"'. V okviru psihoedukacije lahko staršem priporočamo tudi literaturo o kronični bolečini.

Staršem in otroku v okviru psihedukacije na primer rečemo: "Pogovorimo se o tem, kako zaznavamo bolečino in kako delujejo različni bolečinski procesi, da boste lažje razumeli, kakšno vlogo imajo kognitivno-vedenjske tehnike in metode. $V$ vseh naših tkivih in organih so receptorji za bolečino. Ti receptorji pošljejo možganom sporočilo o tem, kje je telo zaznalo bolečino. Nato naši možgani zaznajo fizične in psihološke občutke bolečine - možgani pripišejo bolečini pomen. Pomembno je vedeti, da sporočilo, ki potuje od receptorjev do možganov, ni nespremenljivo - nanj lahko vplivamo. Fizični dejavniki (npr. toplota, hlad) in psihološki dejavniki (kot npr. čustva in misli) lahko spremenijo sporočilo in vplivajo na to, kako bodo možgani interpretirali bolečino. Spremembe v nevrološkem sistemu - od doživljanja neprestane bolečine do negativnih odzivov na bolečino lahko prispevajo $k$ zaznavi bolečine." 


\section{Postavljanje ciljev}

Otroka in starše vprašamo o njihovih pričakovanjih glede obravnave (Palermo, 2012). Pojasnimo, da realen cilj ni, da bi bolečina izginila oziroma je otrok ne bi več doživljal, temveč si želimo zmanjšati vpliv bolečine na otrokovo funkcioniranje. Otroku in staršem na kratko predstavimo tehnike, ki jih navadno uporabljamo pri obravnavi glavobola (tehnike sproščanja, kognitivne tehnike, ukrepi v šoli ipd.) ter jim pojasnimo, da je učinkovitost vsake od tehnik odvisna od posameznega otroka in njegove bolečine (Palermo, 2012).

Pri postavljanju ciljev obravnave si lahko pomagamo $\mathrm{s}$ tako imenovanim modelom petih področij (angl. five areas model) (Williams in Garland, 2002), pri katerem posameznika povprašamo po tem, katere so spremembe na področju njegovih medosebnih odnosov, življenjske situacije, na področju njegovega mišljenja (večkrat razmišlja o bolečini, o tem, kako ne more nečesa početi itd.), vedenja (več počiva oziroma je manj aktiven, manj družaben ipd.), čustvovanja (večkrat je žalosten, jezen ipd.) in telesnega doživljanja (manjkrat je sproščen, ima manj kondicije ipd.), ki so se pojavile s kronično bolečino. Nato posameznik pove, kaj od naštetega bi najraje spremenil, iz česar skupaj oblikujemo cilje obravnave. Cilje skušamo oblikovati v skladu z naslednjimi merili: cilji morajo biti specifični in jasni, merljivi, realni, dosegljivi in časovno opredeljeni. Primeri ustrezno zastavljenih ciljev:

- V času obravnave povečati število strategij za obvladovanje bolečine.

- Samostojno obvladovanje bolečine in nemoteno opravljanje vsakodnevnih dejavnosti kljub bolečini.

- Ostati pri pouku kljub bolečini.

\section{Kognitivno-vedenjske tehnike soočanja s kronično bolečino}

Pogosto otroci ne poznajo veliko strategij spoprijemanja $\mathrm{z}$ bolečino, temveč se večinoma zatekajo $\mathrm{k}$ uporabi ene ali dveh (npr. počitek, medikamentozna terapija). Zato skušamo v kognitivno-vedenjski terapiji kronične bolečine otroku predstaviti druge možne strategije soočanja $\mathrm{z}$ bolečino in ga spodbujati, da jih uporabi pri v vsakodnevnem življenju ter ugotovi, katere izmed predstavljenih oziroma naučenih spretnosti mu najbolje pomagajo.

\section{Tehnike sproščanja}

Raziskave so pokazale, da ima sproščanje lahko veliko pozitivnih učinkov - povečana energija, zmanjšanje mišične napetosti, izboljšano spanje, nižji krvni tlak, zmanjšana bolečina ipd. Še posebej so se tehnike sproščanja izkazale za učinkovite pri pacientih s kroničnim glavobolom (Holden, Deichmann in Levy, 1999). Tehnike sproščanja, ki jih najpogosteje uporabljamo pri pacientih s kronično bolečino, so trebušno dihanje, progresivna mišična relaksacija in imaginacija (Otis, 2007). Tehnike sproščanja navadno predstavimo tako otrokom kot staršem, saj je pri učenju tehnik zelo dobrodošla pomoč staršev.

\section{Delo s starši}

Delo s starši je pomembno, saj študije kažejo na visoko raven stresa staršev otrok s kronično bolečino (Eccleston, Crombez, Scotford, Clinch in Connell, 2004). Prav takoje vloga staršev ključna za učinkovitost kognitivno-vedenjske terapije otrok s kronično bolečino (Sanders, Shepherd, Cleghorn in Woolford, 1994). Starši s svojimi pričakovanji, vrednotami in prepričanji pomembno vplivajo na vedenje otroka ob bolečini (Palermo, 2012; Palermo, Valrie in Karlson, 2014). Zato vedno preverimo pričakovanja staršev glede kognitivno-vedenjske terapije kronične bolečine, povprašamo po predhodnih izkušnjah $\mathrm{z}$ obravnavo otrokove bolečine in o morebitni kronični bolečini pri katerem od staršev. Staršem nudimo tudi psihoedukacijo o kronični bolečini in jim predstavimo pomen socialnega podkrepljevanja ter vzdrževanja z bolečino povezanih vedenj (Fordyce, 1984; Palermo idr., 2010).

\section{Posamezne kognitivno-vedenjske tehnike}

Pri otrocih in mladostnikih, ki imajo številne negativne avtomatske misli, povezane z zaskrbljenostjo glede bolečine, ali izrazito negativna prepričanja glede bolečine ali njenih posledic so kognitivne tehnike še posebej učinkovite (Palermo, 2012). Pri uporabi kognitivnih tehnik za obravnavo kronične bolečine pri otrocih in mladostnikih moramo biti še posebej pozorni na njihove razvojne značilnosti (Garber, Frankel in Herrington, 2016). Kognitivne tehnike so primerne predvsem za šolske otroke in mladostnike. Pri mlajših šolskih otrocih moramo biti pozorni na to, da uporabimo jasno, konkretno razlago konceptov, ki jih uporabljamo, in pri izvajanju tehnik. $\mathrm{V}$ pomoč pri povezovanju misli in čustev nam je lahko slikovno gradivo (npr. risanje oblačkov nad glavo narisane osebe, da bi otroku lažje ponazorili, kaj so to misli ipd.).

Pri obravnavi kronične bolečine pogosto naletimo na otrokovo katastrofiziranje bolečine (Palermo, 2012). Bolj izraženo katastrofično mišljenje glede bolečine je povezano $\mathrm{z}$ zaznano višjo intenziteto bolečine in zmanjšano aktivnostjo otroka in mladostnika (Lynch, Kashikar-Zuck, Goldschneider in Jones, 2006), zato je pomembno, da katastrofične misli prepoznamo in jih skušamo preoblikovati. Ko otroka naučimo prepoznati negativne avtomatske misli in ko razume povezanost med mislimi in čustvi, lahko s pomočjo kognitivne restrukturacije preoblikujemo otrokove negativne avtomatske misli, povezane s kronično bolečino. Otroku razložimo, da gre pri katastrofizaciji za negativne misli, ki povzročijo zaskrbljenost, saj v njih predpostavljamo, da se bodo zaradi bolečine zgodile izrazito slabe, grozne stvari. S pomočjo tehnike kognitivne restrukturacije lahko nato otroku pomagamo preoblikovati oziroma zmanjšati katastrofičnost misli ob bolečini. Otroku lahko kognitivno restrukturacijo predstavimo kot "detektivsko razmišljanje", (Rapee, Wignail, Spence, Cobham in Lyneham, 2008), v katerem si mora zastaviti veliko vprašanj, saj mora detektiv takrat, ko proučuje primer, zelo pozorno proučiti dokaze in ne sme prehitro oblikovati sklepov, saj bi lahko naredil napako. Otroku pomagamo s seznamom vprašanj, s pomočjo katerih bo preučil dokaze za svoje misli: 
- Zaradi česa sem zaskrbljen?

- Kaj se je zgodilo, ko sem imel v preteklosti take misli ali skrbi?

- Kakšna so dejstva?

- Kaj vse se še lahko zgodi?

- Kaj se bo v resnici zgodilo? Kako verjetno je, da se bo to zgodilo?

Ustavljanje misli oziroma tehnika "stop" je še ena od kognitivnih tehnik, ki je namenjena zmanjševanju vpliva negativnih avtomatskih misli glede bolečine ali njenih posledic na funkcioniranje otroka ali mladostnika. Ta tehnika se od kognitivne restrukturacije razlikuje v tem, da se osredini na ustavljanje negativnih avtomatskih misli, kar je še posebej uporabno pri otrocih in mladostnikih s ponavljajočimi se negativnimi avtomatskimi mislimi oziroma ruminiranjem (Palermo, 2012). Te tehnike otroka naučimo potem, ko prepozna, katere (negativne, katastrofične) avtomatske misli glede bolečine in njenih posledic se pojavljajo pri njem. Tehniko "stop" otroku predstavimo kot tehniko, s katero se bo naučil prepoznati, kdaj se pojavijo te negativne misli in kako jih v tistem trenutku ustaviti. Otroka naučimo, da vsakič, ko se pojavi določena negativna avtomatska misel, zakriči "Stop!" in si ob tem predstavlja rdeč znak stop. Kasneje si bo ob negativni avtomatski misli samo predstavljal znak stop, v zadnjem koraku pa skušal negativne avtomatske misli nadomestiti z ustreznejšimi, manj negativnimi mislimi.

Pri otrocih in mladostnikih s kronično bolečino pogosto tudi pridružene motnje (npr. depresivnost, anksioznost) in drugi dejavniki tveganja (npr. vedenje staršev ob bolečini) pomembno prispevajo $\mathrm{k}$ zmanjšani aktivnosti (Fisher in Palermo, 2016; Noel idr., 2016). Raziskave so pokazale, da je pri otrocih in mladostnikih s kronično bolečino pogost upad vedenjske aktivnosti (npr. fizična aktivnost, obiskovanje pouka, druženje s prijatelji, družinske aktivnosti, obisk trgovine ipd.) (Kashikar-Zuck, Goldschneider, Powers, Vaught in Hershey, 2001). Misel na možno bolečino pri posamezniku namreč povzroči, da naredi vse, da bi se izognil bolečini, kar navadno prispeva k manjši aktivnosti (McDonald, 2017). Zato je vedenjska aktivacija in načrtovanje aktivnosti eden od pomembnih delov kognitivno-vedenjske terapije kronične bolečine (Otis, 2007; Palermo idr., 2012). Pri načrtovanju telesne aktivacije skupaj $\mathrm{z}$ otrokom naredimo načrt. Pomembno je, da načrtujemo zmerno aktivacijo, ko posameznik z aktivnostjo preneha in ima počitek, preden se bolečina pojavi ali stopnjuje. Po krajšem počitku nato aktivnost nadaljuje. Cilj je doseči raven, ki jo posameznik še zmore, ne da bi pri tem doživljal bolečino (McDonald, 2017). K načrtovanju vedenjske aktivacije je ravno tako pomembno vključiti starše, saj ti pogosto namesto otroka opravijo številne dejavnosti, ki bi jih otrok sicer zmogel sam. Razložimo jim, zakaj je vedenjska aktivacija pomembna za otroka in kako bo prispevala k izboljšanju stanja (npr. telo, ki je fizično bolje pripravljeno, ki ima več moči, se lažje sooča z bolečino, doživlja bolečino kot manj intenzivno ipd.). Pogosto otroci in mladostniki s kronično bolečino opustijo tudi prostočasne dejavnosti, ki so jih imeli pred pojavom kronične bolečine, kar lahko prispeva k negativnemu razpoloženju in občutku osamljenosti (Palermo idr., 2012). Z otrokom zato najprej oblikujemo seznam idej za pozitivne aktivnosti (npr. poslušanje glasbe, druženje s prijatelji, branje revij, odhod v kino, obisk prijatelja, rolkanje, sprehod s psom ipd.), ki naj vključuje čim več za otroka zabavnih aktivnosti. Nato otrok iz seznama izbere določeno število (npr. tri) dejavnosti, ki jih bo počel v naslednjem tednu.

Ko otroka seznanimo $\mathrm{z}$ nekaterimi kognitivnimi in vedenjskimi tehnikami, namenimo veliko pozornosti spodbujanju, da tehnike uporabi v vsakodnevnem življenju. Vprašamo ga, v katerih konkretnih primerih bi lahko uporabil naučene strategije, in ga spodbujamo, da jih v naslednjem takem primeru poskuša uporabiti. Pri tem so otroku v pomoč starši, ki jih s predstavljenimi tehnikami seznanimo in jih naučimo, kako otroka spodbujajo k učinkovitejšemu soočanju $\mathrm{z}$ bolečino.

Ko so vzročni in vzdrževalni dejavniki nejasni in napori obvladovanja (v smislu 'klasične" kognitivno-vedenjske terapije) niso bili uspešni, nekateri avtorji (npr. Pielech, Vowles in Wicksell, 2017) predlagajo, da je bolje delati na sprejemanju bolečine kot na njenem obvladovanju. Najnovejši trendi pri obvladovanju kronične bolečine se tako poslužujejo pristopov, ki združujejo klasični kognitivno-vedenjski pristop $\mathrm{z}$ novejšimi pristopi, kot je terapija sprejemanja in predanosti (angl. Acceptance and Commitment Therapy) (npr. Wicksell, Olsson in Hayes, 2011). Obravnave težijo k sprejemanju bolečine in ozaveščanju vrednot za dosego izboljšanega celostnega delovanja posameznika. Primarni cilj ni več zmanjšanje stopnje bolečine ali nadzor negativnih misli, ampak spodbuda delovanja posameznika v smislu doseganja vrednot in ciljev, ne glede na bolečino. Uporablja se tehnike izpostavljanja, izkustvene tehnike, trening čuječnosti (angl. mindfulness) s tehniko defuzije in delo na vrednotah. Proces s pacientom spremljamo in ovrednotimo enako kot pri klasični kognitivno-vedenjski terapiji (Hayes in dr., 1999, v McCracken, 2006). V terapiji sprejemanja in predanosti delamo na sprejemanju negativnih misli in občutenj (npr. bolečine) in na vključevanju v aktivnosti, ki so smiselne za posameznika, čeprav sprožijo negativne misli in občutja. Pri obravnavi bolečine tako otroka opogumimo, da izvaja sebi pomembno aktivnost, čeprav le-ta poslabša ali sproži bolečino. Otrok se postopoma distancira od bolečine in ta ima manjši vpliv na njegovo vedenje in posledično življenje (Wicksell, Melin, Lekander, Olsson, 2009).

\section{Sklep}

Kronična bolečina je pogosta težava, s katero se soočajo otroci in mladostniki (King idr., 2011; Perquin idr., 2000). $\mathrm{V}$ zadnjih desetletjih narašča število študij, ki dokazujejo učinkovitost kognitivno-vedenjske terapije pri obvladovanju bolečine (Eccleston, Morley, Williams Eccleston, Morley, Williams, Yorke in Mastroyannopoulou, 2002; Eccelston idr., 2009; Eccleston, Morley in Williams, 2013; Fisher idr., 2014), kar lahko vodi $\mathrm{v}$ pomembno izboljšanje posameznikove kakovosti življenja in zmanjša potrebo po medicinskih ukrepih (Otis, 2007). Ameriško združenje za bolečino v svojih stališčih glede obravnave kronične bolečine otrok in mladostnikov (Palermo idr., 2012) poudarja, da otroci in mladostniki $\mathrm{s}$ kronično bolečino največ pridobijo $\mathrm{V}$ interdisciplinarnih programih, ki v rehabilitacijske programe vključujejo kognitivno-vedenjsko terapijo. Osnovni cilj je, da 
otroci s kronično bolečino dosežejo izboljšanje v celostnem delovanju in v kakovosti življenja.

Pri izvajanju kognitivno-vedenjske terapije pri otrocih s kronično bolečino je pomembno oceniti motivacijo za tovrstno terapijo tako pri otrocih kot pri starših, saj so pričakovanja od terapije pogosto manj realna oziroma je njihova motivacija usmerjena predvsem v odpravljanje bolečine (McDonald, 2017). Pomembno je, da posamezne tehnike $v$ terapiji prilagodimo posamezniku glede na njegove razvojne značilnosti, morebitne pridružene duševne motnje ipd. (McCracken in Turk, 2002). Pristop v terapiji je večravenski in ni usmerjen le na otroka, ampak tudi na njegovo družino, šolo in odnose $\mathrm{z}$ vrstniki.

V slovenskem zdravstvenem sistemu se v obravnavo otrok in mladostnikov vse pogosteje vključujemo tudi kognitivnovedenjski terapevti ( $\mathrm{tj}$. psihologi in zdravniki s končanim izobraževanjem iz kognitivno-vedenjske terapije). $\mathrm{V}$ tem prispevku sva avtorici želeli predstaviti splošne smernice za kognitivno-vedenjsko obravnavo otrok in mladostnikov $\mathrm{s}$ kronično bolečino, ki je glede na svetovne smernice priporočena kot rutinski del obravnave tovrstnih težav (Palermo idr., 2010).

\section{Literatura}

Achenbach, T. M. in Rescorla, L. A. (2001). Manual for the ASEBA School-Age Forms and Profiles. Burlington, VT: University of Vermont, Research Center for Children, Youth and Families.

American Psychiatric Association (2013). Diagnostic and statistical manual of mental disorders, 5th ed. Washington, DC.

Andrasik, F. in Schwartz, M. (2006). Behavioural assessment and treatment of paediatric headache. Behavior Modification, 30(1), 93-113.

Carr, A. (2016): Somatic problems. V A. Carr (ur.): The Handbook of Child and Adolescent Clinical Psychology: A Contextual Approach, 3rd ed. (str. 655-748). East Sussex: Routledge.

Chorpita, B. F., Moffitt, C. in Gray, J. (2005). Psychometric properties of the Revised Child Anxiety and Depression Scale in a clinical sample. Behaviour Research and Therapy, 43, 309-322.

Dahlquist, L. M. in Switkin Nagel, M. (2009). Chronic and Recurrent Pain. V M. C. Roberts in R. G. Steele: Handbook Of Pediatric Psychology, Fourth Ed. (str.153166). New York, The Guilford Press.

Dorn, L. D., Campo, J. C., Thato. S., Dahl, R. E., Lewin, D., Chandra, R. in Di Lorenzo, C. (2003). Psychological comorbidity and stress reactivity in children and adolescents with recurrent abdominal pain and anxiety disorders. Journal of the American Academy of Child and Adolescent Psychiatry, 42, 66-75.

Eccleston, C., Morley, S., Williams, A., Yorke, L. in Mastroyannopoulou, K. (2002). Systematic review of randomised controlled trials of psychological therapy for chronic pain in children and adolescents, with a subset meta-analysis of pain relief. Pain, 99(1-2), 157-165.
Eccleston, C., Crombez, G., Scotford, A., Clinch, J. in Connell, H. (2004). Adolescent chronic pain: Patterns and predictors of emotional distress in adolescents with chronic pain and their parents. Pain, 108(3), 221-229.

Eccleston, C., Palermo, T. M., Williams, A. C., Lewandowski, A. in Morley, S. (2009). Psychological therapies for the management of chronic and recurrent pain in children and adolescents. Cochrane Database of Systematic Reviews, 2.

Eccleston, C., Morley, S. in Williams, A. C. (2013). Psychological approaches to chronic pain management: evidence and challenges. British Journal of Anaesthesia, 111(1), 59-63.

Ehde, D. M., Dillworth, T. M. in Turner J. A. (2014). Cognitivebehavioral therapy for individuals with chronic pain: efficacy, innovations, and directions for research. The American Journal of Psychology, 69(2), 153-66.

Fisher, E., Heathcote, L., Palermo, T. M., de C Williams, A. C., Lau, J. in Eccleston, C. (2014). Systematic review and meta-analysis of psychological therapies for children with chronic pain. Journal of Pediatric Psychology, 39, 763-782.

Fisher, E., in Palermo, T. M. (2016). Goal Pursuit in Youth with Chronic Pain. Children, 3(4), 36.

Fordyce, W. E. (1984). Behavioural science and chronic pain. Postgraduate Medical Journal, 60, 865-868.

Friedrichsdorf, S. J., Giordano, J., Desai Dakoji, K., Warmuth, A., Daughtry, C. in Schulz, C. A. (2016). Chronic Pain in Children and Adolescents: Diagnosis and Treatment of Primary Pain Disorders in Head, Abdomen, Muscles and Joints. Children, 3(4), 42.

Garber, J., Frankel, S. A. in Herrington, C. G. (2016). Developmental Demands of Cognitive Behavioral Therapy for Depression in Children and Adolescents: Cognitive, Social, and Emotional Processes. Annual Review of Clinical Psychology, 12, 181-216.

Goodman, R. (1997). The Strengths and Difficulties Questionnaire: A research note. Journal of Child Psychology and Psychiatry, 38, 581-586.

Hermann, C. (2011). Psychological interventions for chronic paediatric pain: State of the art, current developments and open questions. Pain Management, 5, 473-483.

Holden, E. W., Deichmann, M. M. in Levy, J. D. (1999). Empirically supported treatments in pediatric psychology: recurrent pediatric headache. Journal of Pediatric Psychology, 24(2), 91-109.

Hunfeld J. A., Perquin, C. W., Duivenvoorden, H. J., HazebroekKampschreur, A. A., Passchier, J., van Suijlekom-Smit, L. W. in van der Wouden, J. C. (2001). Chronic pain and its impact on quality of life in adolescents and their families. Journal of Pediatric Psychology, 26, 145-153.

Kashikar-Zuck, S., Goldschneider, K. R., Powers, S. W., Vaught, M. H. in Hershey, A. D. (2001). Depression and functional disability in chronic pediatric pain. The Clinical Journal of Pain, 17(4), 341-349.

Kashikar-Zuck, S., Parkins, I. S., Graham, T. B., Lynch, A. M., Passo, M., ... Richards, M. M. (2008). Anxiety, mood, and behavioral disorders among pediatric patients with juvenile fibromyalgia syndrome. Pain, 24(7), 620-626. 
King, S., Chambers, C. T., Huguet, A., MacNevin, R. C., McGrath, P. J., Parker, L. in MacDonald, A. J. (2011). The epidemiology of chronic pain in children and adolescents revisited: A systematic review. Pain, 152(12), 2729-2738.

Kovacs, M. (1985). The Children's Depression, Inventory (CDI). Psychopharmacology Bulletin, 21(4), 995-998.

Kröner - Herwig, B. in Gassmann, J. (2012): Headache disorders in children and adolescents: Their association with psychological, behavioral and socio-environmental factors. Headache, 52(9), 1387-1401.

Liossi, C. in Howard, R. F. (2016). Pediatric chronic pain: Biopsychosocial assessment and formulation. Pediatrics, 138(5).

Logan, D. E., Simons, L. E., Stein, M. J. in Chastain, L. (2008). School impairment in adolescents with chronic pain. The Journal of Pain, 9(5), 407-416.

Lynch, A. M., Kashikar-Zuck, S., Goldschneider, K. R. in Jones, B. A. (2006). Psychosocial risks for disability in children with chronic back pain. Journal of Pain, 7(4), 244-251.

Martin, A. L., McGrath P., Brown, S. C. in Katz, J. (2007). Anxiety sensitivity, fear of pain and pain-related disability in children and adolescents with chronic pain. Pain Research and Management, 12(4), 267-272.

McCracken, L. M. (2006). Conteporary contextual psychological approaches to assessment and treatment of chronic pain. Rehabilitacija, 1-2(5), 27-30.

McCracken, L. M. in Turk, D. C. (2002). Behavioral and cognitive-behavioral treatment for chronic pain: outcome, predictors of outcome, and treatment process. Spine, 27(22), 2564-2573.

McDonald, H. (2017). Kognitivno-vedenjska terapija pri kronični bolečini. V Starovasnik Žagavec, B., Zadravec, T. in Janjušević, P. (ur.), Novejša spoznanja in kognitivno vedenjski pristopi pri obravnavi različnih skupin klientov v terapevtski praksi (str. 253-264). Društvo za vedenjsko in kognitivno terapijo Slovenije.

Melzack, R. in Wall, P. D. (1965). Pain mechanisms: a new theory. Science, 150(3699), 971-979.

Morley, S., Eccleston, C. in Williams, A. (1999). Systematic review and meta-analysis of randomized controlled trials of cognitive behaviour therapy and behaviour therapy for chronic pain in adults, excluding headache. Pain, 80(1-2), $1-13$.

Nicholson, R. A., Houle, T. T., Rhudy, J. L. in Norton, P. J. (2007). Psychological Risk Factors in Headache. Headache, 47(3), 413-426.

Noel, M., Rabbitts, J. A., Ghafari Tai, G. in Palermo, T. M. (2015). Remembering pain after surgery: A longitudinal examination of the role of pain catastrophizing in children's and parents' recall. Pain, 156(5), 800-808.

Noel, M., Groenewald, C. B., Beals-Erickson, S. E., Gebert, J. T. in Palermo, T. M. (2016). Chronic pain in adolescence and internalizing mental health disorders: a nationally representative study. Pain, 157(6), 1333-1338.

Otis, J. D. (2007). Managing Chronic Pain: A CognitiveBehavioral Therapy Approach, Therapist Guide. Oxford University Press, New York.
Palermo, T. (2012). Cognitive-Behavioral Therapy for Chronic Pain in Children and Adolescents. Oxford University Press, New York.

Palermo, T., Eccleston, C., Lewandowski, A., Williams, A. in Morley, S. (2010). Randomized controlled trials of psychological therapies for management of chronic pain in children and adolescents: An updated meta-analytic review. Pain, 148(3), 387-148.

Palermo, T., Eccleston, C., Goldschneider, K., Larkin McGinn, K., Sethna, N., Schechter, N. in Turner, H. (2012). Assessment and Management of Children with Chronic Pain. A Position Statement from the American Pain Society. Pridobljeno s spletne strani http:// americanpainsociety.org/uploads/get-involved/pediatricchronic-pain-statement.pdf

Palermo, T. M., Valrie, C. R. in Karlson, C. W. (2014). Family and parent influences on pediatric chronic pain: A developmental perspective. American Psychologist, 69(2), 142-152.

Palermo, T. M., Wilson, A. C., Peters, M., Lewandowski, A. in Somhegzi, H. (2009). Randomized controlled trial of an Internet-delivered family cognitive-behavioral therapy intervention for children and adolescents with chronic pain. Pain, 146(1-2), 205-213.

Perquin, C. W., Hazebroek-Kampscheur, A. A. J. M., Hunfeld, J. A. M., Bohnene, A. M., van Suijlekom-Smit, L. W. A., Passchier, J. in van der Wouden, J. C. (2000). Pain in children and adolescents: a common experience. Pain, 87(1), 51-58.

Pielech, M., Vowles, K. E. in Wicksell, R. (2017). Acceptance and commitment therapy for pediatric chronic pain: Theory and application. Children, 4(2), 10.

Rapee, R. M., Wignail, A., Spence, S. H., Cobham, V. in Lyneham, H. (2008). Helping your anxious child, second edition. New Harbinger Publications.

Sanders, M. R., Shepherd, R. W., Cleghorn, G. in Woolford, $H$. (1994). The treatment of recurrent abdominal pain in children: a controlled comparison of cognitive-behavioral family intervention and standard pediatric care. Journal of Consulting and Clinical Psychology, 62, 306-314.

Schechter, N. L. (2014). Functional Pain. JAMA Pediatrics, 168(8), 693.

Sieberg, C., Huguet, A., von Baeyer, C. in Seshia, S. (2012). Psychological interventions for headache in children and adolescents. Canadian Journal of Neurological Sciences, 39(1), 26-34.

Sieberg, C. B., Smith, A., White, M., Manganella, J. Sethna, N. in Logan, D. E. (2017). Changes in maternal and paternal pain-related attitudes, behaviors, and perceptions across pediatric pain rehabilitation treatment: A multilevel modeling approach. Journal of Pediatric Psychology, 42(1), 52-64.

Skevington, S. M. (1998). Investigating the relationship between pain and discomfort and quality of life, using the WHOQOL. Pain, 76(3), 395-406.

Turner, J. A., Mancl, L. in Aaron, L. A. (2006). Short- and long-term efficacy of brief cognitive-behavioral therapy for patients with chronic temporomandibular disorder pain: a randomized, controlled trial. Pain, 121(3), 181-194. 
Wicksell, R. K., Melin, L., Lekander, M. in Olsson, G. L. (2009). Evaluating the effectiveness of exposure and acceptance strategies to improve functioning and quality of life in longstanding pediatric pain--a randomized controlled trial. Pain, 141(3), 248-257.

Wicksell, R. K., Olsson, G. L. in Hayes, S. C. (2011). Mediators of change in Acceptance and Commitment Therapy for pediatric chronic pain. Pain, 152(12), 2792-2801.

Williams, C. J. in Garland, A. (2002). A cognitive-behavioural therapy assessment model for use in everyday clinical practice. Advances in Psychiatric Treatment, 8, 172-179. 